\author{
Lotte Huniche
}

\title{
Studying Genetic Risk in the Conduct of Everyday Life
}

\begin{abstract}
Summary
This article is a revised version of a talk given in lieu of the Ph.D. dissertation: Huntington's Disease in Everyday Life. Knowledge, Ignorance and Genetic Risk (Huniche 2002). The dissertation evolves around the analysis of modern living with risk for a late onset genetic disorder. Here, three aspects of everyday lives faced with Huntington's Disease (HD) are discussed. First, HD is one aspect of everyday living along with a variety of other aspects. The importance of risk is analysed as personal and changing in changing circumstances. Second, genetic knowledge and technology are not solid universals, but situated and changing, and of varying importance in lives at risk. Last, the ethical rationalities of everyday living, research and clinical practice concerned with a hereditary condition are discussed as complex and contradictory in and across structures of social practice.
\end{abstract}

\section{Introduction}

In this paper I address three main dimensions of the empirical study resulting in the submission of the Ph.D. dissertation: Huntington's Disease in Everyday Life: Knowledge, Ignorance and Genetic Risk (Huniche 2002).

\section{The disease of the gene}

Huntington's Disease (HD) is a severe neurological disorder named after the medical doctor, George Huntington (1850-1916), who first described its symptoms and pattern of inheritance (Huntington 1872). Symptoms consist of involuntary movements, loss of motor control and balance. HD affects cognitive abilities like problem solving, judgment, planning and carrying out everyday tasks. Furthermore, HD affects emotional and behavioural aspects of the person (Snowden 1999). Symptoms usually appear between the ages of 35 and 45, but may set in at any age, and progress over a 15-20 year period leading eventually to death. Medical genetics have established a $50 \%$ risk of passing on the mutated gene to any one child. The effect of medical treatment is still rather limited and there is, as yet, no cure. Particularly since the 1980's a great many efforts have been vested in establishing the causes of HD. Following an almost classical mendelian pattern of autosomal dominant inheritance HD has attracted the attention of researchers from various branches of the natural sciences (Harper 1996). In 1993, after an intensive ten-year search, the gene for HD was not just located to the short arm of chromosome 4 , but also specified as consisting of a prolonged CAGrepeat. This was a milestone in the history of researching $\mathrm{HD}$ and it made genetic testing possible (Wexler 1996).

\section{Key dimensions}

Having introduced HD I shall now turn to the actual research project. Below I address the three main dimensions of my study and in 
doing so I shall also address a specific question posed by the evaluation committee for the Ph. D. dissertation, namely "how the results from the study matter as knowledge". In the dissertation I suggest a rather critical stance towards scientific knowledge as the sole and solid foundation for acting and making decisions in everyday life. I propose the same critical stance towards the generation of insights in my own work. In this paper I would like to point out how discussions and insights may be generated from such a critical perspective and still be of use in the conduct of everyday life and professional practice concerned with HD and other hereditary diseases. The key dimensions are: 1) To approach the study of $\mathrm{HD}$ as a part of the concrete conditions for the personal conduct of everyday life and life trajectories for persons facing HD. 2) To consider the importance of genetic knowledge and conceptions of risk for persons in HD families, for professional practice and for research into HD. 3) To address issues of the ethical rationalities in everyday life and professional practice and to look into the notion of the autonomous individual that seems inseparable from this discussion.

\section{Methods and materials}

The study was carried out as practice research in a critical psychological perspective (Holzkamp 1985/1994, Dreier 1993, Mørck 1995, Markard 1987/1991, Nissen 2000) and may also be described as an explorative field study in the broad ethnographic sense. One way of generating empirical materials were participant $o b$ servation in contexts such as the genetic counselling clinic and the Department for Medical Genetics at Copenhagen University, the Danish National Huntington Association, and at various research meetings over the duration of the project period. In these contexts I met persons involved with HD in many ways. They were persons at risk for $\mathrm{HD}$, their children, relatives, friends, professionals and researchers. In addition, I conducted 18 semi-structured interviews. 16 interviews were conducted with members of HD families and these interviews took place in participants homes whenever this was possible. 6 of these participants were at $50 \%$ risk for HD meaning that they knew about HD in their family, that they were not ill at the time, and not tested. 10 participants had previously been tested. 6 were carriers of the HD gene but were not ill, as yet, and 4 did not carry the gene. Additionally, two partners took part in interviews and sometimes a child of the family was about. The remaining 2 interview participants were professionals involved with caring for HD families. As it may be noted the majority of the persons I have met during the study are not ill with HD. I chose not to ask persons who had symptoms of HD for interviews mainly because I could not be entirely certain of their informed consent due to the slowly progressing dementia involved in HD.

\section{HD as part of the conduct of everyday life}

The first dimension that I would like to address entails a discussion of what it means to approach the study of HD as a part of the concrete conditions for the personal conduct of everyday life. Most important, it means that persons and their everyday conduct is the primary locus of attention. HD is not an issue in and by itself but the issue is the role and importance of HD in the lives concerned. Thus the focus is not on disease and risk but on how members of HD families handle their entire life circumstances including aspects of illness and the awareness of risk. This focus is partly a consequence of my point of departure in theories of social practice (Lave 1997, Lave \& Wenger 1997, Dreier 1997). From the perspective that persons participate in ongoing social practice across contexts HD must be viewed as potentially important in 
everyday life to all family members (the ill, the unaffected, the tested, spouses, and other relatives). A further reason for focussing on everyday life rather than illness is that neuropsychological research is already deep into understanding the disease and its progressing symptoms, developing diagnostic tools and various forms of treatment. HD as an ailment comes into my study in other ways. For one, through the perspectives on everyday life of the persons suffering from various stages of HD that I did meet in counselling and other contexts. A couple of these persons were very ill. Second, through the perspectives offered in interviews on the effects of illness in various relatives for other family members, for family relations, and for the conduct of everyday life in general. Thus, in my materials illness figures as important in other ways than those directly related to having symptoms. The importance of illness arises and is played out in ongoing everyday practice where other issues, other kinds of trouble, other preoccupations are also at stake in personal life trajectories as well as for relations.

John's description of his relationship to his mother, who is ill with HD, reflects a common experience of growing up with an ill parent. John remembers his mother as having always been ill. At first she was diagnosed with arthritis and stopped working when John was around 9 years old. Some years later she was completely "run down", as John puts it. She would be going to bed late at night, getting up in the afternoon, walking and jerking around for hours not able to get herself organised or to have a decent conversation. John grieves the fact that when he grew old enough to have a proper discussion with her she was no longer capable.

Also important, the focus on everyday life made me re-think the main concepts I was confronted with when I first engaged in the practices of the Department for Medical Genetics and the genetic counselling clinic at the University of Copenhagen. Those concepts were 1) hereditary disease, 2) persons at risk, 3) genetic testing. My approach to the field made for different concepts to become central to my analysis and I find the comparison illuminating: These concepts are 1) personal conduct of everyday life, 2) persons in HD families, 3) knowledge and risk in everyday life. I have worked out and worked with these concepts from a theoretical standpoint within critical psychology (Holzkamp 1985, Dreier 1993, Nissen 1998), just as my general approach draws on the social sciences and thus come to point to a different set of issues in lives faced with HD than do the former concepts. The former concepts prevail not just in genetic research but also in clinical practice. They are concepts arising primarily from the perspectives of researchers and professionals, and draw, at least in part, on genetic determinism as a frame for understanding HD. The latter concepts are worked out in order to grasp the perspectives of persons in HD families. They are intended to be useful by pointing to aspects of living with the awareness of HD that are commonly overlooked, on the basis of a personal perspective in concrete circumstances, where coming to an understanding with oneself of the situation is a gradual process. Such aspects of living everyday lives in a HD family were conveyed throughout my fieldwork (Huniche 2002). My materials point to the importance of HD being similar but also variable even for persons who share similar circumstances. HD may have a negative or no particular effect in the personal lives of various family members. HD may occupy persons more or less according to their concrete life circumstances. This means that the personal significance, or insignificance, of $\mathrm{HD}$ is rarely identical even where this might be expected. The importance of HD may vary greatly for persons within the same age group, who occupy a comparable position within the family, for example as the youngest sibling or as a partner, and for persons who have found 
out about HD at a similar point in life. Having said this, it is also clear that similar issues are at stake for persons in similar circumstances, that similar circumstances commonly produce similar kinds of trouble even if this is also specific to each person. This is one reason why for example partners or persons who are tested positive may find it helpful to exchange their experiences. Barry and James are examples of persons who share certain circumstances. They are in their 30és, they have known about HD in their respective families for years, and they are both tested. They share common problems in everyday life arising from growing up with a parent who gradually turns into someone almost unrecognisable. They both talk about difficult visits to the nursing home, self-reproach for not being able to do more, their own awareness of risk for HD, going through the emotional turmoil of genetic testing, living with a test result and making decisions in the light of this. But there are important differences between their everyday lives.

Barry is living by himself and he is tested negative. So is his younger sibling. Their mother has suffered greatly because of her husbands' illness, but she is doing the best she has in years. Contrary to what one might expect Barry is experiencing serious emotional problems. He goes through periods of confusion, sadness and lack of initiative, which prevents him from seeing friends, dating, and generally making his life work out. He spends much time alone or working long hours. Barry attributes his problems to the personal and familial turmoil he has been through partly because of the devastating importance of HD for his family. After his fathers diagnosis Barry settled his mind and reduced the insecure feeling of being at risk by arriving at the conclusion that he would probably get ill himself. His life was then turned upside down when he was tested negative. After the test he has felt obliged but unable to make something of his life.

In comparison, James is living with his girl- friend and is tested positive. He has also been through some rough patches. He is a single child and he was still in his teens when his mother was diagnosed and his father died with a heart condition. The only other relative James has any contact with is of no support, much to James' regret. Nevertheless, James enjoys a successful career and has recently bought a house with his girlfriend. They are settled with good friends and they are contemplating having a baby.

I would also like to mention Helen and Andrew who are partners and make up an example of sharing the same circumstances but from two different positions within the family. They describe finding out about HD in Helens' family as having transformed their lives. The situation is particularly troublesome for Andrew who is not personally at risk. He is questioning his values and priorities in life to an extent where he can hardly function in everyday life. The choice to leave his former wife and children is shed in an entirely new light due to the unexpected threat of disease to Helen and to their young child. Andrew wonders whether this is a kind of "punishment" for breaking up his former family. Both Helen and Andrew continually scrutinise their priorities as career persons working long hours. The sudden death of a friend their own age has added to feelings of insecurity about how long they will each be allowed to live. Even so, Helen does not think of herself as equally devastated. She does not allow herself to become affected to an extent were she cannot live up to her obligations as a mother, wife, and a working person. Her main focus is to make things at home and between them work out. She is more concerned about the present situation, finding ways of hanging in there, than about the possible horrors of the future.

My materials also show that the importance of HD is not fixed or static in any one personal life. Rather, the importance of HD varies and changes over time with changes in concrete 
personal circumstances. Therefore I have also studied how, when and why HD becomes important, or not, in the accounts of personal life trajectories. Looking biographically at persons in HD families I point not only to changing personal importance of HD over time and across contexts, but also to how the trajectories of various family members, their ways of conducting life, their understandings of the situation and their decision, may be, and often is, both differing and of great importance to other family members. For example, both Gale and Marianne talk about the changing importance of HD in their lives. Gale experienced a time of great frustration and preoccupation with HD just after her mother was diagnosed. But Gale is in her early 20's and concerned with qualifying for further education and enjoys a variety of spare time activities. Gradually over the first year of finding out the negative importance of HD lessens and Gales' concerns are centred round specific issues, i.e. telling her boyfriend, contacting her father. Marianne conveys how the conduct of her 3 siblings ended up having far-reaching consequences for her own life. Upon finding out about HD Marianne had settled for not having the test, but as her 3 siblings were tested negative one by one, she experienced a gradual build-up of personal pressure to have the test. She felt that her odds for "being in the clear" were lessened by each of her siblings negative test results. In order to settle her own mind she decided to have the test and it turned out to be positive. Adding to Mariannes' frustration was the fact that she and her siblings had all agreed that no one would tell the others of their test results until everyone had been tested. Marianne appreciates their motives for telling being the conveyance of "the good news" to their mother, but the broken promise fuels Mariannes' feelings of injustice and has profound implications for their mutual relationships.

\section{Knowledge and risk in everyday life}

The second dimension entails a discussion of what genetic knowledge and conceptions of risk mean in the everyday lives of persons living in HD families. I found the discussion important as knowledge in medical genetics as well as notions of risk establish the most widely accepted associations between illness and everyday life with HD and so amount to the most powerful conceptions of HD in the field. Furthermore, knowledge in medical genetics is widely staged as beneficial and necessary in order to conduct life in a responsible and acceptable manner. In the context of medical genetics knowledge becomes an almost unquestionable resource and risk calculation an integral part of weighing out alternative courses of action. Moral values, what is deemed right and wrong, gets tied to pursuing, possessing and utilising knowledge. Knowing and acting in moral accordance with one's knowledge becomes the better way of conducting everyday life. In my work I question such widespread notions of knowledge as universal, fixed and true. On the other hand I do not subscribe to a social constructionist view of knowledge as a mere product of human thought and interaction. Rather, I argue that we need to understand how associations are made and maintained, or left to decay, between the bodily or material on the one hand, and the understandings, explanatory models and derived social practices on the other. I argue how various knowledge claims within medical genetics have evolved over time to become sound associations and how these associations are reflected in everyday, activist and professional practices. Changes in knowledge claims make for changes not just in research but also in the concrete contexts of counselling, activism and everyday life. By reflecting how these historically changing knowledge claims have been and still do become important to persons 
in HD families in different ways we may get a better idea of the possibilities and limitations in everyday life that arise from them rather than putting our faith blindly into knowledge about genes and risk to provide solid and unproblematic answers.

My materials indicate that knowledge about $\mathrm{HD}$ in the everyday lives of the concerned is more a question of finding out and handling the implications of HD than about knowing and applying facts. Facts may be a more or less central part of the gradual process of coming to an understanding with oneself and of making life work. Facts matter more or less in personal decision making processes. Knowledge of HD as part of the family heritage cannot be pinned down as of any specific kind or tied to any one event. The process of finding out and coming to an understanding with oneself of facts, implications, and new circumstances arising from HD may last for years. Awareness of HD, just as various facts about inheritance, risk and medical technologies, is commonly in and out of focus throughout personal life trajectories. Concrete circumstances and consequences of HD change and so does the relevance of knowledge.

In my materials there are 3 characteristic ways of finding out about HD. 1) The sudden shock of finding out about HD when it comes "out of the blue" without prior warning. 2) The feeling that something is wrong without one knowing exactly what. Persons in HD families may live with such awareness for years before finally tying a name to it. 3) HD may sometimes be an integral part of the personal life trajectory when persons have known and related to the diagnosis and its consequences all their lives.

The "naming" or "labelling" of HD as a severe genetic disorder may serve as a relief just as it may sometimes be experienced as devastating news. Even though genetic knowledge and conceptions of risk are played out in various forms in everyday life, sometimes assuming an all-encompassing importance and sometimes hardly recognised at all, the overall impact of this kind of knowledge on how we perceive conduct and decision making in HD families is profound. I argue that personal conduct of everyday life with HD cannot but be reasoned on the basis of genetic knowledge in isolation nor does genetic knowledge provide unprolematic answers. However critical this may sound, it is not the insights from medical genetics per se that I am sceptical about, as much as the staging of this kind of knowledge as providing the right answers and the moral yardstick for proper conduct.

\section{The ethical rationality of everyday life}

As a third dimension I address the ethical rationality of everyday life and professional practice. I do so because of the present preoccupation with ethics and morality in relation to genetic research, professional practice and concerning the everyday decisions in families with known hereditary conditions. From my materials it is clear that moral judgement is readily passed, just as it is common to evaluate ones own conduct and decisions with respect to moral soundness. Moral judgement about the conduct of everyday life is commonly argued with reference to knowledge about genetics and risk and with reference to courses of action supported by technology, like for example presymptomatic or prenatal testing. Genetic knowledge is commonly referred to as the proper foundation for making the right decisions and acting responsibly and thus the moral prompting is to know and to act. Implicitly, this amounts to the claim that the answer to responsible everyday decision making is to be found in knowledge and technology.

I suggest that this kind of moral prompting rests on the glorification of genetic knowledge and along with that the marginalisation of other kinds of knowledge. If knowledge is, 
as I suggest, best understood as partial, local and changing then our confidence in and use of genetic knowledge claims must take into consideration the limitations of its scope and usability. Further, I suggest that the modern notion of the autonomous individual complicates choices and courses of action. The common notion of autonomy entails an understanding of the individual as educated, personally responsible and capable of making the right moral choices (Taylor 1991). I argue that if we view personal conduct solely from the perspective of autonomy we cannot take into account important aspects of the social relatedness characteristic of human lives. Autonomous morality is blind to the contradictions of living and choosing in social relations. Not seeking out information or making use of available technologies is hard to argue from the perspective of the autonomous individual but may be staged as morally sound if consequences for entire family network are considered.

I also suggest that a particular responsibility rests with professionals in genetic counselling and other areas of assisting persons with hereditary diseases to take into account the limitations of informed and technology supported courses of action. For quite a number of persons in my materials genetic knowledge is useful and sometimes relieving, but it is also problematic and does not always represent an easy way of fixing a complex life situation. Knowing does not necessarily make decisions any easier, but surely complicates matters with respect to making moral judgements. Making use of genetic technologies has its drawbacks that may undermine the moral solidity of the chosen course of action. For example, a couple might want to make sure that their baby is not at risk for HD by means of pre-natal genetic testing. This attempt at acting responsibly is somewhat modified by the risk of having to abort an affected foetus. It is not possible to ascertain whether an affected foetus is to become ill at a young age or live to be eighty before symptoms occur. Therefore the choice of abortion is not straightforward. Furthermore, in my materials everyday conduct and decisions are argued with reference to notions of responsibility, duty, right, or consequences, and equal arguments are brought into play even if they lead to opposite effects. For example the notion of responsible parenthood may lead both to having and not having a child with risk for HD if for example termination is deemed immoral. Differing circumstances make for different priorities and diverse evaluations of what matters make for differing courses of action.

\section{Concluding remarks}

I have finally arrived at drawing up the concluding remarks to the question of "how the results from the study matter as knowledge". It matters as knowledge about the possibilities and limitations of knowledge and the associated technologies within medical genetics. The notion of rationality in the enlightenment tradition is present in most, if not all, contemporary claims to knowledge, but rationality in this sense is but one relevant aspect of knowledge in ongoing social practice. I conceive of genetic knowledge as situated and practiced in concrete social contexts. Associations between the material on one hand and understandings and practices on the other are continually negotiated and changing. A staggering example is how the number of CAG-repeats in the genetic makeup of a person at risk for HD is associated with age at onset of symptoms and risk of inheritance and how this association is continually revised and refined. Equally, morality and ethics are produced historically and culturally as values and imperatives that become part of the circumstances in which persons involved with hereditary disease conduct their everyday lives, make and carry out decisions. These values and imperatives are important with respect to how such persons may establish themselves and how they come to be viewed by others as responsible 
and accountable or not. Furthermore, values and imperatives are part of establishing and developing research, technology and professional practice within medical genetics and should be considered as such. I argue that no one, neither Colin who is described as repressing the fact that he is at risk, David and Beth who want a child with no risk, although David does not want a genetic test himself, nor the stances and practices of professional counsellors and researchers are best helped by any formulation of a general rule or by way of calculating happiness against suffering in a traditional utilitarian sense. My stance towards morality in conduct of everyday life and professional practice draw on the Aristotelian tradition of weighing out and reflecting circumstances and alternative courses of action in practice. This also means that individual autonomy has to be situated in the larger communities. Drawing on the work of philosophers like Uffe Juul Jensen (1996) and Mariana Valverde (2002) I suggest ethics to be a question of deciding on certain principles to serve as a sounding board when considering concrete ways of acting in social practice. A principle like "the responsibility for the week and the vulnerable" (Jensen 1995) is thus a stance towards human relations and societal makeup, but it is also a political statement that conveys the kind of practical consequences of a moral argument that one wants to support. If morality is not a question of legitimising the use of power but rather a defence and a manifestation against oppression then we must consider how genetic knowledge and medical technologies are used as tools in this struggle.

\section{References}

Dreier, O. (1993). Psykosocial behandling. Copenhagen: Dansk Psykologisk Forlag.

Dreier, O. (1997). Subjectivity and Social Practice. Center for Health, Humanity, and Culture. Department of Philosophy, Aarhus University.

Harper, P. S. (Ed.) (1996). Huntington's Disease. Major problems in neurology 33, Saunders.
Holzkamp, K. (1985). Grundlegung der Psychologie. Frankfurt/M: Campus Verlag.

Holzkamp, K. (1994). Am Problem vorbei. Zusammenheitsblindheit der Variablenpsychologie. Forum Kritische Psychologie 28, 5-19.

Holzkamp, K. (1998). Daglig livsførelse som subjektvidenskabeligt grundbegreb. Nordiske Udkast 2, 3-32, Dansk Psykologisk Forlag.

Huntington, G. (1872). On Chorea. The Medical and Surgical Reporter, 26, 320-321.

Jensen, U. J. (1995). Moralsk ansvar og menneskesyn. Munksgaard, 2. Edition.

Jensen, U. J. \& Andersen, (Eds.) (1995). Sundhedsbegreber. Filosofi og praksis. Philosophia.

Lave, J. (1997). Learning, apprenticeship, social practice. Nordisk Pedagogik, 140-151.

Lave, J. \& Wenger, E. (1991). Situated learning. Legitimate peripheral participation. Cambridge: Cambridge University Press.

Markard, M. (1987). Kategorien, Theorien, Empirie in subjektwissenschaftlicher Forschung. Zum Verhältnis von Theorie und Praxis in der Psychologie, Bericht von der 4.Internationalen Ferienuniversität Kritische Psychologie, VA \& G.

Markard, M. (1991). Metodik subjektwissenschaftlicher Forschung. Jenseits des Streits um quantitative

und qualitative Methoden. Berlin/Hamburg: Argument Verlag.

Mørck, L. L. (1995). Praksisforskning som metode, teori og praksis. Udkast 1, 34-78.

Nissen, M. (1998). Brugerindflydelse og handlesammenhoenge i psykosocialt arbejde. Center for Health, Humanity, and Culture. Department of Philosophy, Aarhus University.

Nissen, M. (2000). Practice research: Critical psychology in and through practices. Annual Reiew of Critical Psychology 2, 145-181.

Snowden, J. (1999). Behavioural Problems in Huntington's Disease. Published in the Huntington's Disease Association Newsletter, Great Britain.

Taylor, C. (1991). The ethics of Authenticity. Harvard: Harvard University Press.

Valverde, M. (2002). Experience and truth telling: Intoxicated autobiography and ethical subjectivity. Outlines 1, 3-18. 